\title{
Effects of the period of glyphosate treatment on oak seedlings: phenological and physiological aspects
}

\author{
C. Fabert ${ }^{1,2}$, H. Frochot ${ }^{1}$ and P. Dizengremel 2 \\ 1 Station de Sylviculture, INRA-CRF, Champenoux, 54280 Seichamos, and \\ 2 Laboratoire de Physiologie Végétale et Forestière, Université de Nancy I, BP 239, 54506 \\ Vandœuvre-lès-Nancy, France
}

\section{Introduction}

Young oak trees are very sensitive to weed competition, especially brambles (Rubus fruticosus L.). Bramble control is essential during the first years of establishment of oak regenerations. Glyphosate ( $N$-phosphonomethylglycine) enables good control when applied in winter to green brambles (Frochot and Wehrlen, 1983).

However, the tolerance of oak seedlings to the glyphosate treatments during the vegetative rest period was not clearly established. Previous studies demonstrated that glyphosate applied during the dormant period did not affect poplar growth (Netzer and Hauser, 1983). Unfortunately this herbicide sometimes causes injuries to oak seedlings. Young oaks were shown to be as equally affected by glyphosate applied at the beginning as at the end of the rest period (Frochot et al., 1981). In this study, we analyzed the effects of the period of herbicide application on phenological and physiological characteristics of oak seedlings.

\section{Materials and Methods}

1 yr old oak seedlings (Quercus petraea (M.) Liebl.) were grown on fertilized peat in individual containers. Each treatment and control consisted of 24 seedlings.

Experiments were carried out in a climate chamber simulating autumn and winter conditions during 8 periods of $14 \mathrm{~d}$ each. These periods were characterized by ranges of medium $(1,5,8)$, high $(2,4,6)$ and low $(3,7)$ temperatures (Fig. 1). The seedlings were subjected to an accidental period of low temperature indicated by an asterisk. The day-night regime was established as follows: 8 $h d$ at a temperature equal to the maximum average temperature of the corresponding period (cf. Fig. 1).

All seedlings were subjected to the same climatic sequences (1-8). 8 groups of seedlings were subjected to a single herbicide application at 8 different periods, treatment $T n$ being applied in the middle of the period of temperature $n$. Glyphosate $2160 \mathrm{~g} /$ ha $(6 \mathrm{ltha}$ Roundup) in aqueous solution was applied with an automatic sprayer.

The height of main shoots was measured during the following July. Some enzyme activities linked to carbohydrate breakdown pathways were measured in leaves (nkat mg $^{-1}$ protein) during the spring following the herbicide application: NAD-gal-3-PDH or NAD- 


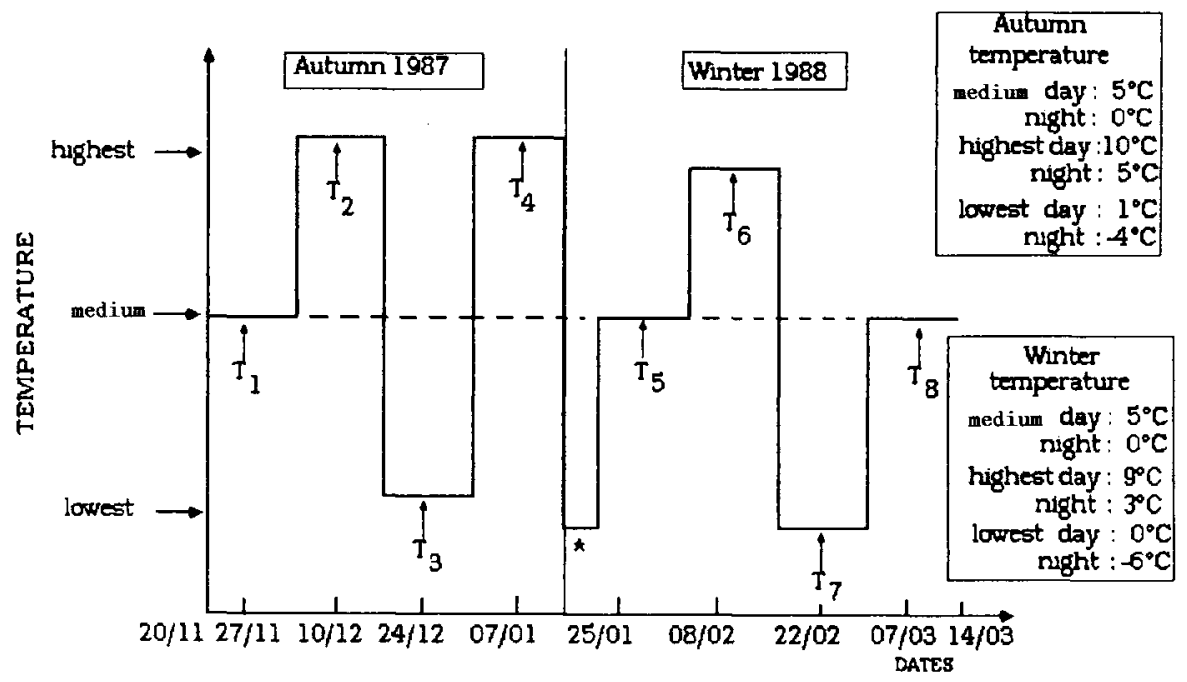

Fig. 1. Scheme of the experimental protocol used for herbicide application. All treatments and controls were subjected to the same climatic sequences $1-8$. The herbicide was applied once only in each treatment $\left(T_{1}\right.$ to $\left.T_{8}\right)$ in the middle of the corresponding climatic period. *: technical incident.

gluyceraldehyde-3-phosphate dehydrogenase (cytosolic glycolysis) and NADP-gal-3-PDH or NADP-glyceraldehyde-3-phosphate dehydrogenase (chloroplastic pathway) (Heber et al., 1963). Fumarase (Hatch, 1978) and NAD-malic (NAD-ME) (Grover et al., 1981; Gerant et al., 1989) were used as mitochondrial markers. A pentose phosphate pathway enzyme (G-6-PDH or glucose-6-phosphate dehydrogenase) was also measured (Pitel and Cheliak, 1986).

\section{Results}

\section{Phenological effects}

All treatments showed a significant depressive effect on shoot elongation as compared to the control (Fig. 2). A maximum effect was observed for $T_{1}$ and $T_{2}$, and later for $T_{7}$ and $T_{8}$. Glyphosate caused symptoms of phytotoxicity, stretching and thickening of the leaves, and shortening of the shoots. Damage was particularly marked in the first treatments $\left(T_{1}\right.$ and $\left.T_{2}\right)$ and decreased from $T_{2}$ to $T_{8}$. Only a few alterations were still apparent in the last treatment $\left(T_{8}\right)$.

\section{Enzyme activities in leaves}

Decreases in the activities of NAD-ME, fumarase, NAD- and NADP-gal-3-PDH were observed (Fig. 3), especially for the autumn and spring treatments. In contrast, the G-6-PDH activity was strikingly stimulated by treatments $T_{1}$ and $T_{2}$. The magnitude of the changes in enzyme activities was more marked for autumnal treatments than for winter treatments.

\section{Discussion}

A period of 6 mo separated the winter glyphosate treatments from the physiological 


\section{$826 s$}

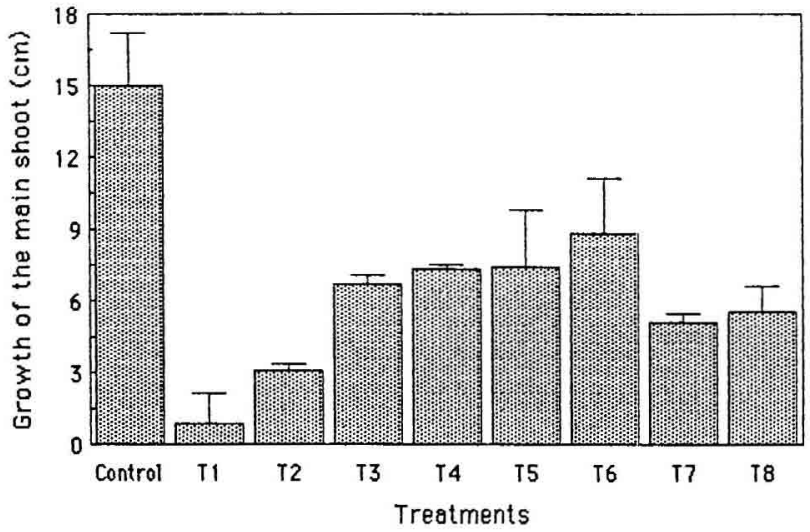

Fig. 2. Effect of the period of a glyphosate application on the spring elongation of oak shoots. Vertical bars indicate \pm standard deviation.

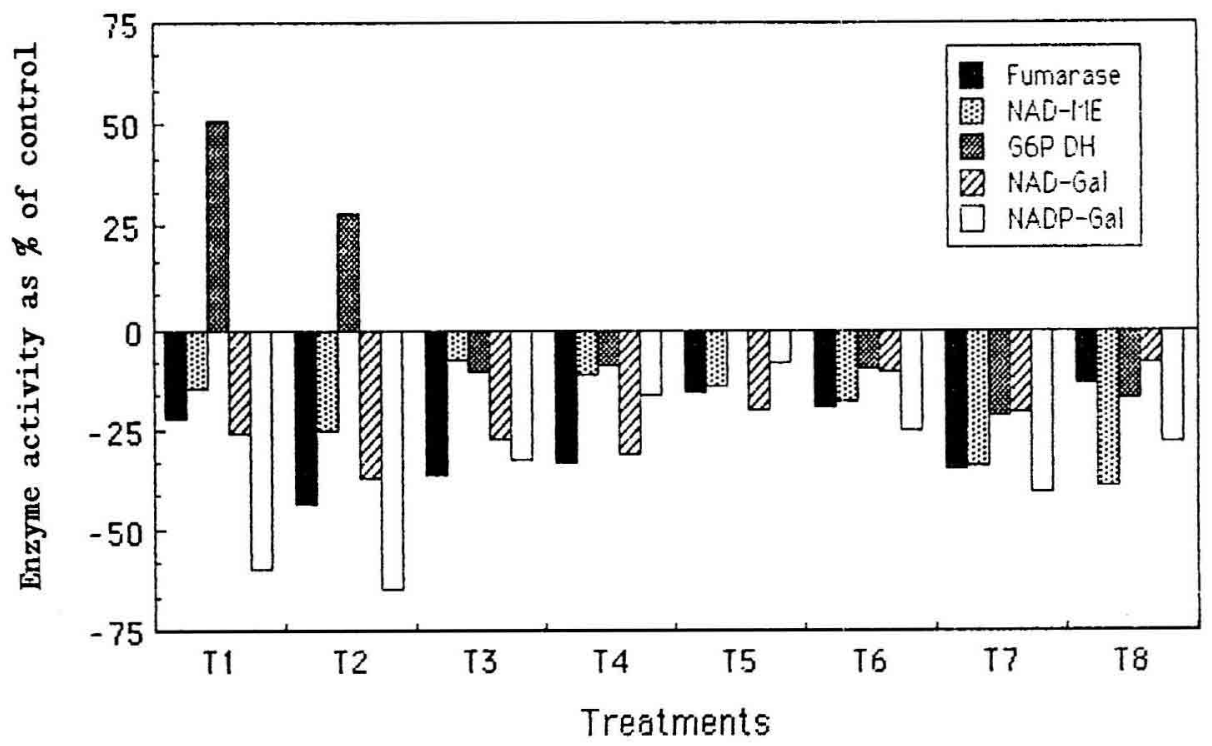

Fig. 3. Enzyme activities in leaves from oak seedlings subjected to glyphosate applied at different periods. All the presented values are averages from at least 3 independent experiments. The coefficient of variation never exceeded $20 \%$.

and phenological analyses carried out after bud-break. These results show clearly that effects of glyphosate were never correlated with temperature. On the other hand, maximum depressive effects appeared following autumn application and later with application just before budbreak. They indicate a possible seasonal effect. However, the temperatures used during the experiment did not take into account possible peaks of low temperature or moisture variations. 
A decrease in all enzyme activities was commonly observed except for treatments $T_{1}$ and $T_{2}$, when herbicide was applied in autumn with normal and high temperatures. This corresponds to deep growth disturbances. The increases in G6-PDH activity observed in the first 2 treatments might be linked to severe stress, possibly revealing the synthesis of compounds linked to thick cellular growth, as has often been observed (Dizengremel and Citerne, 1989; Koziol et al., 1988).

These preliminary results show that there is a cortical penetration of glyphosate during the cold season, particularly important at the end of the summer growth period and just before bud-break. The marked changes in enzyme activities reveal a sensitivity of oak seedlings to glyphosate, as shown clearly by shoot growth reduction, mainly when the herbicide was applied at the beginning of the autumnal period.

\section{References}

Dizengremel P. \& Citerne A. (1988) Air pollutant effects on mitochondria and respiration. In: Air Pollution and Plant Metabolism. (SchulteHostede S., Derrall N.M., Blank L.W. \& Wellburn A.R., eds.), Elsevier, London, pp. 169188

Frochot H. \& Wehrlen L. (1983) Efficacité d'herbicides sur la ronce (Rubus fruticosus L.) en forêt pendant la saison froide. In: $12^{\circ}$ Conférence Columa, Unesco, Paris. 3, 345-352

Frochot H., Pitsch M. \& Wehrlen L. (1981) Sélectivité du glyphosate en fonction de la dose appliquée et du stade végétatif des jeunes plants forestiers, résineux et feuillus. In: 110 Conférence Columa, ANPP, Paris. 2, 545-553

Gerant D., Citerne A., Fabert C. \& Dizengremel P. (1989) Extraction and study of enzymes linked to malate metabolism in tree leaves. Ann. Sci. For. 46 suppl., 811s-814s

Grover S.D., Canellas P.F. \& Wedding R.T. (1981) Purification of NAD malic enzyme from potato and investigations of some physical and kinetic properties. Arch. Biochem. Biophys. 209, 396-407

Hatch M.D. (1978) A simple spectrophotometric assay for fumarate hydratase in crude tissue extracts. Ann. Biochem. 85, 271-275

Heber U., Pon N.G. \& Heber M. (1963) Localization of carboxy dismutase and triose phosphate dehydrogenase in chloroplasts. Plant Physiol. 38, 355-360

Koziol M.J., Whatley F.R. \& Shelvey J.D. (1988) An integrated view of the effects of gaseous air pollutants on plant carbohydrate metabolism. In: Air Pollution and Plant Metabolism. (SchulteHostede S., Darrall N.M., Blank L.W. \& Wellburn A.R., eds.), Elsevier, London, pp. 148168

Netzer D.A. \& Hauser E.A. (1983) Controlling weeds in poplar by dormant season glyphosate overspray. North Central Weed Control Conference 38, 141-142

Pitel J.A. \& Cheliak W.M. (1986) Effectiveness of protective agents for increasing activity of five enzymes from vegetative tissues of white spruce. Can. J. Bot. 64, 39-44 